\title{
Central activities of hydroalcoholic extract from Lafoensia pacari A. St.-Hil. stem bark
}

\author{
Pablinny Moreira Galdino ${ }^{1}$, Marcus Vinícius Mariano Nascimento ${ }^{1}$, Fábio Borges de Sousa ${ }^{1}$, \\ Reginaldo Nassar Ferreira1, José Realino de Paula ${ }^{2}$, Elson Alves Costa ${ }^{1, *}$ \\ ${ }^{1}$ Laboratory of Pharmacology of Natural Products, Institute of Biological Sciences, Federal University of Goiás, \\ ${ }^{2}$ Research Laboratory of Natural Products, Pharmacy Faculty, Federal University of Goiás
}

\begin{abstract}
Lafoensia pacari A. St.-Hil. can be found from Amapá to Rio Grande do Sul states, and also in Paraguay and Bolivia. It is popularly known as pacari or mangava-brava and is used to promote weight loss, as an anti-thermal or tonic, to treat gastritis, ulcers, scarring, itching, discouragement, and cancer. In the open field tests, the hydroalcoholic extract from L. pacari stem bark (HEP) decreased the number of rearings, number of invaded squares, and increased immobility time compared to control animals. In the pentobarbital-induced sleep time test, HEP decreased latency time to sleep and increased sleeping time. In the rota-rod test, no changes in the studied parameters were observed. In the elevated plus maze, HEP increased the percentage time and percentage entries in the open arms, indicating that this extract exerts an anxiolytic-like activity.
\end{abstract}

Uniterms: Lafoensia pacari A. St.-Hil./pharmacognosy. Hydroalcoholic extract. Central Nervous System/ experimental study. Anxiety/experimental study.

Lafoensia pacari A. St.-Hil., uma espécie vegetal presente no Brasil, do Amapá ao Rio Grande do Sul, no Paraguai e na Bolívia, é popularmente conhecida como pacari ou mangava-brava e é utilizada como emagrecedor, cicatrizante, antitérmico, tônico e para tratar gastrite, úlcera, coceira, desânimo e câncer. No teste do campo aberto, o tratamento com o extrato hidro-alcoólico de pacari (HEP) reduziu o número de rearings e o número de quadrados invadidos além de aumentar o tempo de imobilidade dos animais em relação ao controle. No sono induzido por pentobarbital sódico o tratamento com HEP causou redução na latência e aumento na duração do sono. No rota-rod, o tratamento com HEP não alterou os parâmetros observados. No teste de labirinto em cruz elevado, com o tratamento com HEP foi observado aumento do percentual do tempo de permanência e de entradas nos braços abertos, caracterizando uma atividade tipo ansiolítica.

Unitermos: Lafoensia pacari A. St.-Hil/farmacognosia. Extrato etanólico. Sistema Nervoso Central/ estudo experimental. Ansiedade/estudo experimental.

\section{INTRODUCTION}

Some time ago the World Health Organization (WHO) reported that about $80 \%$ of the population in developing countries used some kind of traditional medicine in primary health care, emphasizing the use of herbal products (Farnsworth et al., 1985). According to Farnsworth et al. (1985), up until 1985, of the 119 chemicals extracted

\footnotetext{
*Correspondence: E. A. Costa. Universidade Federal de Goiás, Instituto de Ciências Biológicas, Departamento de Ciências Fisiológicas, CP 131, 74001970 - Goiânia - GO, Brasil. E-mail: xico@icb.ufg.br
}

from plants and used in medicine, 74\% were first discovered through popular knowledge. Koehn \& Carter (2005) reported that around $25 \%$ of prescribed drugs worldwide were obtained directly or indirectly from plants. Moreover, about $50 \%$ of drugs developed between 1981 and 2002 were obtained from natural products, semi-synthetic analogues or synthetic compounds based on natural products (Koehn, Carter, 2005).

In this context, Brazil is well endowed because it ranks top among the 17 richest countries in biodiversity in the world, possessing approximately $20 \%$ of total species on the planet (Rates, 2001). The abundance of plant 
specimens, animals and microorganisms in the Brazilian ecosystem, undoubtedly represents an important differentiator in drug development (Kato, 2001).

In the state of Goiás, the medicinal plants are often used as an alternative therapy. Among the plants used is Lafoensia pacari A. St.-Hil., known popularly as "pacari" or "mangava-brava". L. pacari is a shrub-like plant from the Lythraceae family that grows in the Brazilian Savannah, gallery forest, dry forest and altitude forest ecosystems. It is also found from Amapá to Rio Grande do Sul states, and also in Paraguay and Bolivia (Santos, 2006).

In folk medicine, the leaves and stem bark are used in decoction or macerated (in white wine) forms for healing to treat gastric disturbances such as gastritis and ulcers (Pott, Pott, 1994; Vieira et al., 2000; Silva, 1998). Other popular uses include for treating wounds, itching, discouragement, as well as slimming (Tonello, 1997), and as an antipyretic or tonic (Mundo, Duarte, 2007). In Paraguay, the stem bark is used as a decoction to treat cancer (Solon et al., 2000).

Several studies have demonstrated the antimicrobial activity of $L$. pacari stem bark and leaf extracts (Lima et al., 2006; Alves et al., 2000), antiviral activity against Herpes simplex virus type 1 (Müller et al., 2007), antiinflammatory, analgesic and anti-edematous activities (Rogério et al., 2003, 2006, 2007; Matos et al., 2008), antioxidant and anticancer activity of the stem bark (Solon et al., 2000), anti-secretory gastric activity by inhibition of $\mathrm{H}^{+} \mathrm{K}^{+}$-ATPase pump (Murakami et al., 1991), as well as potential for using this plant specimen in the treatment of dyspepsia (Menezes et al., 2006). Matos et al. (2008) demonstrated the sedative effect of aqueous extract from stem bark of this plant.

Phytochemical studies on alcoholic extracts from $L$. pacari resulted in the isolation and identification of gallic and ellagic acids, with the latter compound being considered the major factor responsible for the anti-oxidant and anticancer (Solon et al., 2000), anti-secretory gastric (Murakami et al., 1991), anti-inflammatory and anti-edematous (Rogério et al., 2006) activities of this vegetal specimen.

The aim of this study was to evaluate the pharmacological activity of ethanol extract from $L$. pacari stem bark on the central nervous system (CNS), in order to enhance and characterize the depressant effect observed in the aqueous extract, as an anxiolytic-like action.

\section{MATERIAL AND METHODS}

\section{Plant Material}

The stem bark of Lafoensia pacari was collected from the plants in their natural habitat of the savannah region of Bela Vista - Goiás state, Brazil ( $837 \mathrm{~m}, 16^{\circ} 58^{\prime}$ 54.2" S/40 55' 45.1" W) in October 2005 during their fructification. The plant material was authenticated by Prof. Dr. José Realino de Paula, a Pharmacognosy teacher at the Pharmacy Faculty of the Federal University of Goiás (UFG) and a voucher specimen was deposited at the Herbarium of the UFG under number UFG-27031.

\section{Preparation of Hydroalcoholic Extract from $L$. pacari (HEP)}

L. pacari stem bark was ground in a Wiley Model knife mill. The hydroalcoholic extract from L. pacari (HEP) was obtained by maceration in 70\% hydro-alcoholic solution at the proportion of $5 \%$, under agitation for 72 hours, followed by filtration and concentration under vacuum at $60^{\circ} \mathrm{C}$. The extraction yielded $16.1 \%$, compared to the powder. At the time of use, the solvent was evaporated and HEP was dissolved in saline $(0.9 \%)$.

\section{Animals}

The animals used in this study were male Swiss albino mice, weighing approximately $30 \mathrm{~g}$ from the Central Animal House of the UFG. The animals were kept in a room with controlled temperature $\left(25 \pm 1^{\circ} \mathrm{C}\right)$ and lighting (light/dark cycle of $12 \mathrm{~h}$ ) and food and water ad libitum. Animals were kept in the laboratory for an adaptation period of at least one hour before the experiments were run, with tests usually conducted from 9:00 a.m. to 3:00 p.m. All experimental protocols were developed in accordance with the principles of ethics and animal welfare recommended by the Brazilian College of Animal Experiments COBEA (2006) and this study was approved by the Ethics Commission of the UFG $\left(n^{\circ}-104 / 08\right)$.

\section{Pharmacological Methods}

\section{Effects on Gross Behavior}

Experimental groups of mice ( $\mathrm{n}=5$ per group) were treated orally (p.o.), intraperitoneally (i.p.) or subcutaneously (s.c.) with HEP at doses of 10, 30, 100, 300 and $1000 \mathrm{mg} / \mathrm{kg}$, whereas control groups received vehicle (saline $10 \mathrm{~mL} / \mathrm{kg}$ ) by the same routes. The animals were observed in free ambulation on a flat surface for 3 minutes, at 5, 10, 20, 30 and 60 minutes, 4, 8, 24 and 48 hours after the treatments and again after 4 and 7 days of treatment. The observed effects were noted using a standard pharmacological screening approach, adapted from that described by Malone (1977). This methodology provided the optimal route and dose for the other "in vivo" biological tests. 


\section{Open-Field Test}

This test was based on the methodology described by Siegel (1946) and validated by Archer (1973), and allowed assessment of stimulant or depressant activity. We used groups of 9 mice pre-treated (p.o.) with vehicle, $\operatorname{HEP}(100$, 300 , or $1000 \mathrm{mg} / \mathrm{kg}$ ) or diazepam (1 or $5 \mathrm{mg} / \mathrm{kg}$ - used as positive control). Sixty minutes after the treatment, the animals were placed in the center of an open-field arena made of acrylic, with the bottom divided into nine squares of equal area. Animals were observed for 5 minutes and their exploratory activity (number of squares crossed), number of rearings, grooming and fecal bolus were counted while immobility time was also recorded.

\section{Rota-Rod Test}

The rota-rod test is used to assess if the treatment promotes motor incoordination by sedation and/or muscle relaxation (Dunham, Miya, 1957). In this test, the animals were pre-selected in a training session 24 hours before the test based on their permanence on the bar (at $12 \mathrm{rpm}$ ) for 2 minutes. Groups of the pre-selected animals $(n=9)$ were treated (p.o.) with vehicle (saline $10 \mathrm{~mL} / \mathrm{kg}), \operatorname{HEP}(100$, 300 , or $1000 \mathrm{mg} / \mathrm{kg}$ ) or diazepam (1 or $5 \mathrm{mg} / \mathrm{kg}$ - used as positive control) and after 60 minutes the animals were placed on the bar, to evaluate the number of falls and the time of permanence, where the maximum time allowed was 1 minute and the maximum number of falls allowed was three.

\section{Pentobarbital-Induced Sleep Time}

We used groups of 9 mice pre-treated (p.o.) with vehicle (saline $10 \mathrm{~mL} / \mathrm{kg}), \operatorname{HEP}(100,300$, or $1000 \mathrm{mg} / \mathrm{kg})$ or diazepam ( 1 or $5 \mathrm{mg} / \mathrm{kg})$. Sixty minutes after the treatment, the animals received sodium pentobarbital $50 \mathrm{mg} /$ kg i.p., and the time elapsed between the administration of pentobarbital until the loss of the righting reflex was recorded as the sleep latency, and the time elapsed between the loss and voluntary recovery of the righting reflex was recorded as total sleeping time (Carlini, Burgos, 1979).

\section{Elevated Plus Maze Test}

We used groups of 9 mice pre-treated (p.o.) with vehicle (saline $10 \mathrm{~mL} / \mathrm{kg}$ ), HEP $(100,300$, or $1000 \mathrm{mg} / \mathrm{kg}$ ) or diazepam (1 mg/kg - used as positive control). Sixty minutes after the treatment the animals were individually placed at the center of the plus maze (Maze for mice in acrylic - EP 150, purchased from Insight Scientific Equipment) with their nose facing the direction of one of the closed arms, and observed for 5 minutes (Lister, 1987; Pellow et al., 1985). The test occurred under a red light and was fully recorded for later analysis, which consisted of counting the number of entries into open and closed arms, and the time spent by the animal in the open (OAT), and closed (CAT) arms. Time spent in open arms was later converted into a percentage $(\%$ OAT $=[($ OATx 100$) /$ $(\mathrm{OAT}+\mathrm{CAT})])$. The total number of entries in open and closed arms was used as a measure of locomotor activity and the percentage of time and number of entries into open arms were used as a measure of anxiety.

\section{Statistical Analysis}

Results were expressed as means \pm standard error of mean (SEM) or median with confidence limit. Statistical differences between experimental groups were detected by analysis of variance (ANOVA) followed by Tukey's test. For models without normal distribution, analysis was performed using Kruskal-Wallis's test followed by Dunn's test. Effects were considered significant at $P<0.05$.

\section{RESULTS}

\section{Effects on gross behavior}

Animals treated with HEP intraperitoneally (i.p.) decreased their spontaneous ambulation, showed analgesia (assessed through the pain reaction caused by the compression of distal portion of the tail) and sedation, and two deaths occurred by this route at the dose of 1000 $\mathrm{mg} / \mathrm{kg}$ (within 8 hours of the treatment) and one at dose of $300 \mathrm{mg} / \mathrm{kg}$ (within 24 hours of the treatment). Animals treated with HEP subcutaneously (s.c.) decreased their spontaneous ambulation and showed analgesia, but one death occurred at the dose of $1000 \mathrm{mg} / \mathrm{kg}$ (within 48 hours of the treatment). Among the doses tested orally (p.o.) only 300 and $1000 \mathrm{mg} / \mathrm{kg}$ decreased the animals' spontaneous ambulation movements and showed analgesia and no deaths occurred by this route where the lower dose did not change the assessed parameters.

\section{Open-Field Test}

HEP $(1000 \mathrm{mg} / \mathrm{kg}$ ) decreased the total number of squares crossed by $41 \%$, compared with control group, and also increased the immobility time. The other doses did not alter these parameters. Number of fecal bolus was reduced by all three doses of $\operatorname{HEP}(100,300$ and $1000 \mathrm{mg} /$ $\mathrm{kg}$ ). The doses of 300 and $1000 \mathrm{mg} / \mathrm{kg}$ decreased rearing, whereas grooming was not altered by the treatment. Animals treated with diazepam at a dose of $1 \mathrm{mg} / \mathrm{kg}$ showed an increase in squares crossed and a decrease in fecal bolus whereas at a dose of $5 \mathrm{mg} / \mathrm{kg}$ showed a decrease in the 
squares crossed, rearing and fecal bolus, and an increase in immobility time (Table I).

\section{Rota-Rod test}

None of the HEP doses altered the number of falls or time of permanence of the animal on the rota-rod test (Table II), whereas diazepam $(5 \mathrm{mg} / \mathrm{kg})$ increased the number of falls and decreased the time of permanence on this test.

\section{Pentobarbital-induced sleep time}

Treatments with HEP at doses of 300 or $1000 \mathrm{mg} /$ $\mathrm{kg}$ significantly decreased sleep latency from $180.5 \pm$ 8.1 seconds (control) to $152.9 \pm 4.3$ and $144.4 \pm 5.7$ seconds, respectively (Figure 1), and significantly increased sleeping time from $82.2 \pm 8.01$ minutes (control) to $154.88 \pm 11.2$ and $223.22 \pm 22.8$ minutes, respectively (Figure 2). The sleep latency and sleeping time were not affected by the treatment with HEP $100 \mathrm{mg} / \mathrm{kg}$. Animals treated with diazepam ( 1 or $5 \mathrm{mg} / \mathrm{kg}$ ), used as positive controls in the test, decreased sleep latency and increased sleeping time.

\section{Elevated Plus Maze test}

Treatment with HEP at doses of 100, 300 and 1000 $\mathrm{mg} / \mathrm{kg}$ did not alter the total entries in the open and closed arms, but the percentage of entries into the open arms as well as the percentage of permanence time in open arms were increased by the treatments with HEP at doses of 300 and $1000 \mathrm{mg} / \mathrm{kg}$, and with diazepam (Table III).

\section{DISCUSSION}

Central depressant effects of medicinal plants can provide therapeutic benefits in the treatment of anxiety disorders, which represent a significant social cost as a result of individual suffering, and indirect social costs including reduced productivity (Stein, Seedat, 2004). Among the undesirable effects of drugs used as tranquilizers include impairment of motor activity, reduction in conditioned reflexes, decreased alertness and also sedation, thereby justifying the constant search for new drugs with fewer side effects.

Effects on gross behavior caused by treatment with HEP are suggestive of central depressant drugs, such as decreased spontaneous ambulation and presence of anal-

TABLE I - Effects of hydroalcoholic extract from Lafoensia pacari (HEP) on the open field test, 60 minutes after treatments

\begin{tabular}{|c|c|c|c|c|c|}
\hline Experimental group & Squares crossed & Rearings & Groomings & Fecal bolus & Immobility time (s) \\
\hline Control & $62.60 \pm 3.80$ & $41.17 \pm 3.00$ & $4.00 \pm 0.87$ & $5.57 \pm 0.84$ & $7.42 \pm 3.20$ \\
\hline HEP $100 \mathrm{mg} / \mathrm{kg}$ & $58.33 \pm 4.11$ & $34.14 \pm 6.15$ & $4.50 \pm 0.60$ & $2.00 \pm 0.27^{* *}$ & $6.00 \pm 1.77$ \\
\hline HEP $300 \mathrm{mg} / \mathrm{kg}$ & $49.00 \pm 3.15$ & $21.83 \pm 4.50^{*}$ & $5.42 \pm 0.84$ & $1.86 \pm 0.67 * *$ & $29.25 \pm 4.21$ \\
\hline HEP $1000 \mathrm{mg} / \mathrm{kg}$ & $37.88 \pm 4.39 *$ & $18.83 \pm 2.49 * *$ & $6.00 \pm 1.17$ & $1.80 \pm 0.58 * * *$ & $51.40 \pm 4.90 * *$ \\
\hline DZP $1 \mathrm{mg} / \mathrm{kg}$ & $87.4 \pm 6.10^{*}$ & $52.45 \pm 4.9$ & $5.79 \pm 2.10$ & $2.7 \pm 0.68 *$ & $3.1 \pm 1.8$ \\
\hline DZP 5 mg/kg & $30.20 \pm 8.66^{* *}$ & $7.17 \pm 2.50 * * *$ & $2.33 \pm 1.17$ & $1.00 \pm 0.63 * * *$ & $83.20 \pm 17.65^{* * *}$ \\
\hline
\end{tabular}

Data expressed as mean \pm SEM of nine mice. Control: vehicle (saline, $10 \mathrm{~mL} / \mathrm{kg}$, p.o.), HEP: Hydroalcoholic extract from Lafoensia pacari stem bark (p.o.), DZP: Diazepam (p.o., positive control). ${ }^{*} p \leq 0.05, * * p \leq 0.01, * * * p \leq 0.001$ compared with control group.

TABLE II - Effects of hydroalcoholic extract from Lafoensia pacari (HEP) on the rota-rod test, 60 minutes after treatments

\begin{tabular}{lcccc}
\hline Experimental group & \multicolumn{2}{c}{ Numbers of falls } & \multicolumn{2}{c}{ Time of permanence (s) } \\
\cline { 2 - 5 } & Median & Confidence limit & Median & Confidence limit \\
\hline Control & 0 & $0-0.3$ & 60 & $60-60$ \\
HEP 100 $\mathbf{~ m g / k g ~}$ & 0 & $0-0.7$ & 60 & $60-60$ \\
HEP 300 $\mathbf{~ m g / k g ~}$ & 0 & $0-0.8$ & 60 & $60-60$ \\
HEP 1000 mg/kg & 1 & $0-1.3$ & 60 & $60-60$ \\
DZP 1 mg/kg & 1 & $0.4-1.5$ & 58 & $51-59$ \\
DZP 5 mg/kg & $3^{* * *}$ & $2.3-3$ & $40^{* * *}$ & $37-48$ \\
\hline
\end{tabular}

Data expressed as median and confidence limits of nine mice. Control: vehicle (saline, $10 \mathrm{~mL} / \mathrm{kg}$, p.o.), HEP: Hydroalcoholic extract from Lafoensia pacari stem bark (p.o.), DZP: Diazepam (p.o., positive control). ${ }^{*} p \leq 0.05, * * p \leq 0.01, * * * p \leq 0.001$ compared with control group. 


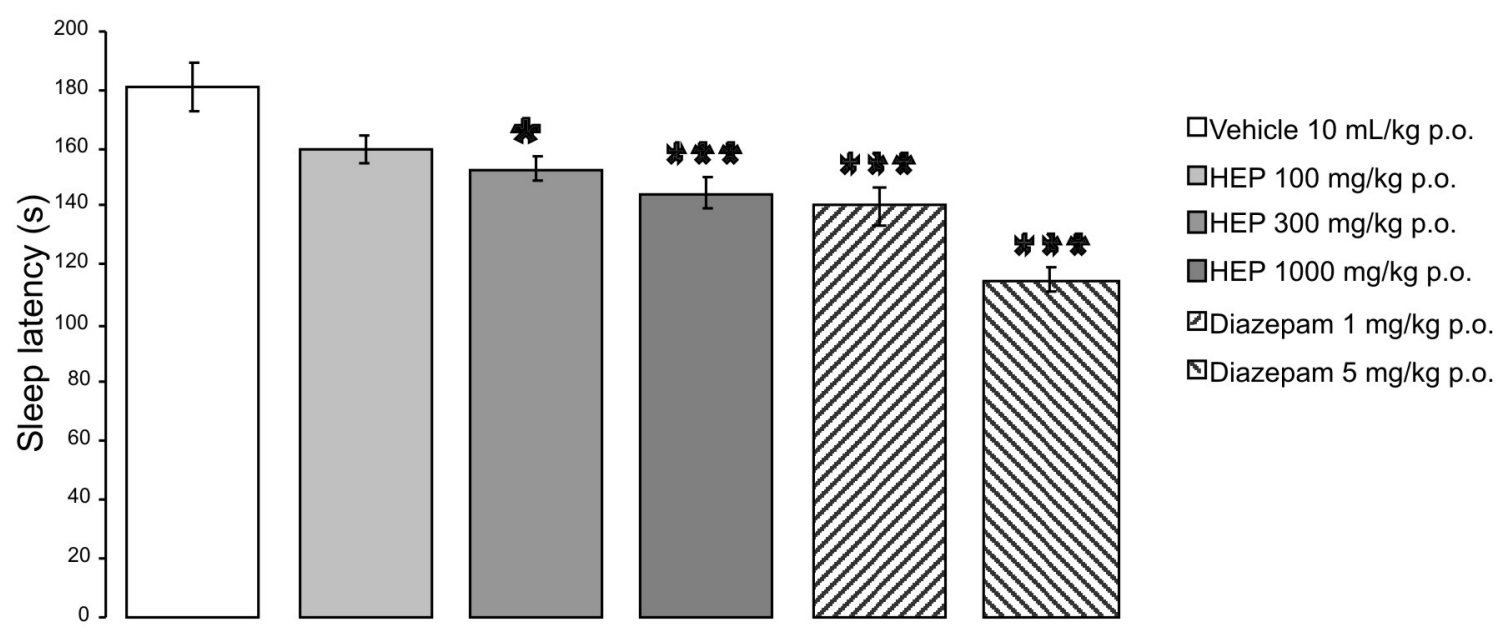

FIGURE 1 - Effect of hydroalcoholic extract from Lafoensia pacari on sleep latency (s) in pentobarbital-induced sleep time test in mice $(\mathrm{n}=9)$ pre-treated (60 min, p.o.) with vehicle (saline, $10 \mathrm{~mL} / \mathrm{kg})$, hydroalcoholic extract from Lafoensia pacari stem bark (HEP, 100,300 or $1000 \mathrm{mg} / \mathrm{kg}$ ) or diazepam (DZP, 1 or $5 \mathrm{mg} / \mathrm{kg}$ ). The columns and vertical bars express means $\pm \mathrm{SEM}$. * $p \leq 0.05$, $* * p \leq 0.01, * * * p \leq 0.001$ compared with control group.

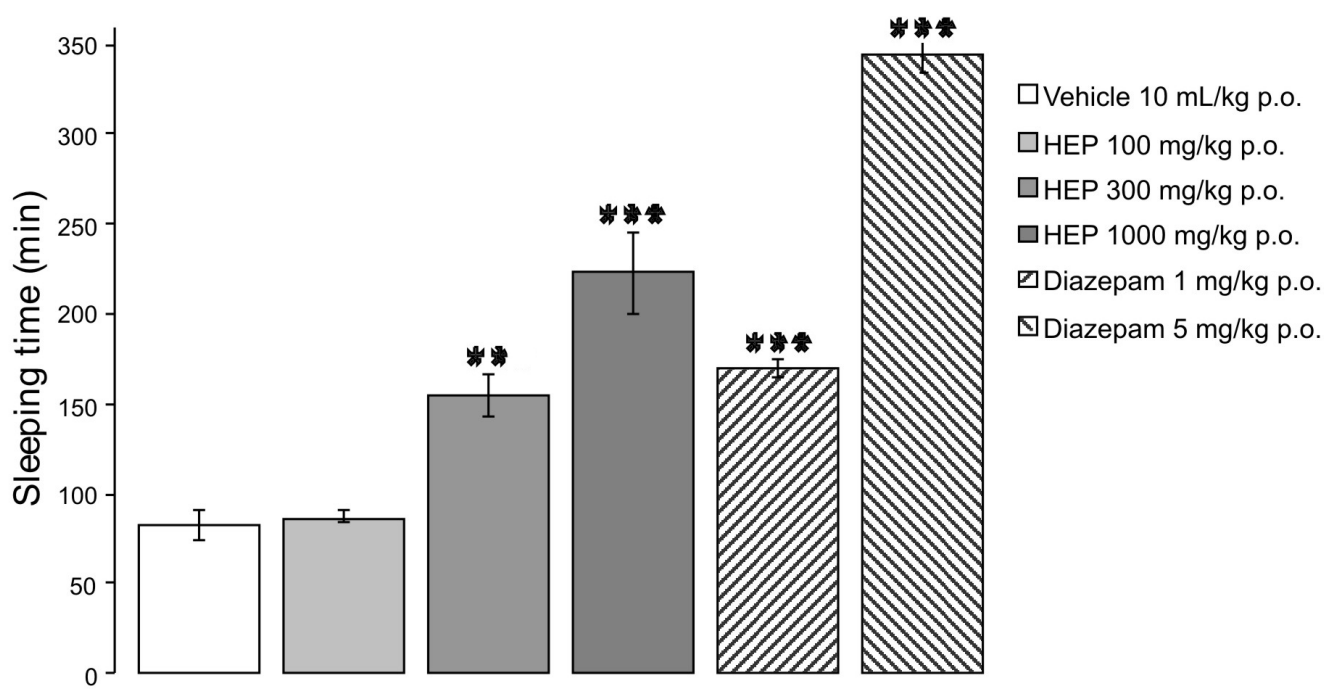

FIGURE 2 - Effect of hydroalcoholic extract from Lafoensia pacari on sleeping time (min) in pentobarbital-induced sleep time test in mice $(\mathrm{n}=9)$ pre-treated $(60 \mathrm{~min}$, p.o.) with vehicle (saline, $10 \mathrm{~mL} / \mathrm{kg})$, hydroalcoholic extract from Lafoensia pacari stem bark (HEP, 100, 300 or $1000 \mathrm{mg} / \mathrm{kg}$ ) or diazepam (DZP, 1 or $5 \mathrm{mg} / \mathrm{kg}$ ). The columns and vertical bars express means \pm SEM. $* * p \leq 0.01, * * * p \leq 0.001$ compared with control group.

TABLE III - Effects of hydroalcoholic extract from Lafoensia pacari (HEP) on elevated plus maze test, 60 minutes after treatments

\begin{tabular}{lccc}
\hline Experimental group & $\begin{array}{c}\text { Total entries in open and } \\
\text { closed arms }\end{array}$ & $\begin{array}{c}\text { Percentage of entries in open } \\
\text { arms }\end{array}$ & $\begin{array}{c}\text { Percentage of time in open } \\
\text { arms }\end{array}$ \\
\hline Control & $23.00 \pm 1.25$ & $37.49 \pm 3.69$ & $40.37 \pm 6.16$ \\
HEP 100 $\mathbf{~ m g / k g}$ & $23.78 \pm 1.89$ & $36.80 \pm 3.90$ & $41.93 \pm 6.27$ \\
HEP 300 $\mathbf{~ m g / k g ~}$ & $26.55 \pm 1.77$ & $54.14 \pm 2.46^{*}$ & $61.88 \pm 3.61^{*}$ \\
HEP 1000 $\mathbf{~ m g / k g}$ & $26.22 \pm 1.77$ & $52.37 \pm 2.79^{*}$ & $60.78 \pm 3.21^{*}$ \\
DZP 1 $\mathbf{~ m g / k g}$ & $24.11 \pm 1.60$ & $74.55 \pm 4.16^{* * *}$ & $72.35 \pm 4.94^{* * *}$ \\
\hline
\end{tabular}

Data expressed as mean \pm SEM of nine mice. Control: vehicle (saline, $10 \mathrm{~mL} / \mathrm{kg}$, p.o.), HEP: Hydroalcoholic extract from Lafoensia pacari stem bark (p.o.), DZP: Diazepam (p.o., positive control). $* p \leq 0.05, * * p \leq 0.01, * * * p \leq 0.001$ compared with control group. 
gesia. Considering the absence of deaths throughout the period of observation in the group of mice treated orally, this route is most promising for further evaluations. We observed changes in animals' behavior only from doses of $300 \mathrm{mg} / \mathrm{kg}$ and greater, and therefore the doses of 100,300 and $1000 \mathrm{mg} / \mathrm{kg}$ were selected for further tests to verify a dose-response relationship over this range.

Despite the deaths following the administration of higher doses of crude extract through the intraperitoneal and subcutaneous routes, these plant extracts are not considered toxic in acute oral treatment. This was evidenced by Lago (2004) who showed that the $\mathrm{LD}_{50}$ in rats was not achieved even at the dose of $5.0 \mathrm{~g} / \mathrm{kg}$, and by Menezes et al. (2006) who used a dose of $1.0 \mathrm{~g} / \mathrm{kg}$ daily in human volunteers in a study on the therapeutic use of Lafoensia pacari extract in Helicobacter pylori eradication. The deaths caused by intraperitoneal and subcutaneous routes may have been due to the presence of saponins in its constitution (Galdino et al., 2009), since most of the molecules of this class of secondary metabolites have hemolytic activity (Schenkel et al., 2004).

Five parameters were evaluated in the open field test: total number of squares crossed (assessing animal exploratory activity and may be affected by CNS-acting drugs or peripheral muscle relaxants), number of rearings and grooming, and immobility time (assessing degree of sedation or fear (anxiety) and may be altered by anxiolytic and anxiogenic drugs), and lastly, number of fecal bolus that can be altered by spasmolytics and spasmogenic drugs or drugs that alter animal emotionality, whereas this parameter can also be reduced by anxiolytic drugs (Archer, 1973; Siegel, 1946).

HEP decreased fecal bolus from doses of $100 \mathrm{mg} /$ $\mathrm{kg}$ and greater, decreased number of rearings from 300 $\mathrm{mg} / \mathrm{kg}$, and at the dose of $1000 \mathrm{mg} / \mathrm{kg}$ decreased squares crossed while increasing immobility time, although grooming remained altered. Similar effects were observed after treatment with diazepam $5 \mathrm{mg} / \mathrm{kg}$. These results suggest a CNS depressant activity or motor incoordination.

To verify if the data obtained in the open field test were due to animal motor incoordination caused by the extract we used the rota-rod test, a classic test to evaluate motor coordination, where an increase in number of falls or decrease in permanence time indicates motor incoordination (Dunham, Myla, 1957). Neither the number of falls or the permanence time were altered by the treatment with HEP, suggesting that the reduction in the number of squares crossed and the increase in immobility time were not due to motor incoordination, but possibly due to central depressant activity.

Continuing with investigation of the central depres- sant activity initially observed in the open field test, we assessed HEP effects on pentobarbital-induced sleep time. In this test, substances that are CNS depressant typically increase sleeping time produced by pentobarbital, and may also decrease sleep latency (Carlini, Burgos, 1979). Agonists of binding sites located on GABA receptor type A (Chweh et al., 1987; Lancel, 1999), such as benzodiazepines, exhibit these effects, evidenced primarily by prolonging the sleeping time. The treatments with diazepam or HEP at doses of 300 and $1000 \mathrm{mg} / \mathrm{kg}$, produced a reduction in sleep latency and an increase in sleeping time, reinforcing the depressant activity attributed to the crude extract. However, some factors that interfere with barbiturate metabolism can result in false positives using this methodology (Carlini, Burgos, 1979), a phenomenon that does not seem to occur with HEP, because the treatment with the extract increased sleeping time and reduced sleep latency, where this reduction does not occur in false positive results in this model.

This CNS depressant activity may be due to an anxiolytic-like activity of the extract and to assay this activity the elevated plus maze test was used, perhaps the most widely employed anxiety animal model. Animals' (rats or mice) natural behavior is to display aversion to open spaces, represented by avoidance of the open arms. The elevated plus maze test tries to simplify and mimic the animal "anxiety-state" which arises in an intensified form in stressful or anxiogenic conditions (Belzung, Griebel, 2001; Bertoglio, Carobrez, 2005).

The effectiveness of the anxiolytic drug in the elevated plus maze test is illustrated by a significant increase in exploratory parameters for open arms (percentage of time and entries into open arms), while the opposite is true for anxiogenic drugs, without changes in motor activity, represented by total entries into open and closed arms (Lister, 1987; Vasconcelos et al., 2004; Bertoglio, Carobrez, 2005; Rodgers, Cole, 1994).

Treatment with the extract at doses of 300 and 1000 $\mathrm{mg} / \mathrm{kg}$ increased the exploratory parameters on open arms without changes in motor activity, results similar to those obtained in animal treated with diazepam at a dose of $1 \mathrm{mg} /$ $\mathrm{kg}$. Therefore, the results obtained in the present study using the hydroalcoholic extract from Lafoensia pacari A. St.-Hil. stem bark suggest an anxiolytic-like activity.

\section{CONCLUSION}

The results of this study allow us to conclude that hydroalcoholic extract of Lafoensia pacari A. St.-Hil. stem bark produced acute CNS depression without altering motor coordination of the animals. This depressant action involves an anxiolytic-like activity at doses that 
do not impair motor activity. Through purification of the crude extract and identification of active compounds the mechanisms of action can be characterized.

\section{ACKNOWLEDGEMENTS}

The authors are grateful to Dr. Ekaterina A. F. B. Rivera and Jackson Nascimento de Lima for ethical and technical assistance. Thanks are also due to FUNAPE/UFG, PRPPG/ UFG, CAPES and PIBIC/CNPq for financial support.

\section{REFERENCES}

ALVES, T. M. A., SILVA, A. F., BRANDÃO, M., GRANDI, T. S. M., SMÂNIA, E. F. A., SMÂNIA JR., A., ZANI, C. L. Biological screening of brazilian medicinal plants. Mem. Inst. Oswaldo Cruz., v.95, n.3, p.367-373, 2000.

ARCHER, J. Tests for emotionality in rats and mice: a review. Anim. Behav., v.21, n.2, p.205-235, 1973.

BELZUNG, C.; GRIEBEL, G. Measuring normal and pathological anxiety-like behaviour in mice: a review. Behav. Brain Res., v.125, n.1-2, p.141-149, 2001.

BERTOGLIO, L.; CAROBREZ, A.P. Ethological and temporal analyses of anxiety-like behavior: the elevated plus-maze model 20 years on. Neurosci. Biobehav. Rev., v.29, n.8, p.1193-1205, 2005.

CARLINI E.A.; BURGOS, V. Screening farmacológico de ansiolíticos: Metodologia laboratorial e comparação entre diazepam e clorobenzepam. Rev. Assoc. Bras. Psiquiatria, v.1, n.1, p.25-31, 1979.

CHWEH, A.Y.; SWINYARD, E.A.; WOLF, H.H. Hypnotic action of pentobarbital in mice: a possible mechanism. Exp. Neurol., v.97, n.1, p.70-76, 1987.

\section{COLÉGIO BRASILEIRO DE EXPERIMENTAÇÃO} ANIMAL. Princípios Éticos Para O Uso De Animais De Laboratório. Available at: $<$ http://www.cobea.org.br/index. php?pg=Principios\%20Eticos>. Accessed on: 24 ago. 2004.

DUHAM, N.W. \& MIYA, T.S. A note on a simple apparatus for detecting neurological deficit in rats and mice. J. Am. Pharm. Assoc. v.46, n.3, p.208-209, 1957.

FARNSWORTH, N.R., AKERELE, O.; BINGEL, A.S.; SOERJATO, D. D.; GUO, Z. Medicinal plants in therapy. Bull. World Health. Org.. v.63, n.6, p.965-981, 1985.
GALDINO, P.M.; NASCIMENTO, M.V.M.; SAMPAIO, B.L.; FERREIRA, R.N.; PAULA, J.R.; COSTA, E.A. Antidepressant-like effect of Lafoensia pacari A. St.-Hil. ethanolic extract and fractions in mice. J. Ethnopharmacol. v.124, n.3, p.581-585, 2009.

KATO, M.J. Global phytochemistry: the Brazilian approach. Phytochemistry, v.57, n.5, p.621-623, 2001.

KOEHN, F.E.; CARTER, G.T. The evolving role of natural products in drug discovery. Nat. Rev. Drug Discov., v.4, n.3, p.206-220, 2005.

LAGO, Kelly Munhóz. Estudos preliminares sobre o potencial toxicológico do extrato aquoso (macerado e decocto) de Lafoensia pacari St. Hil (mangava-brava). Campo Grande, 2004. 84 p. [Monografia de graduação. Faculdade de Farmácia. Universidade para o Desenvolvimento do Estado e da Região do Pantanal].

LANCEL, M. Role of GABA $A_{A}$ receptors in the regulation of sleep: initial sleep responses to peripherally administered modulators and agonists. Sleep, v.22, n.1, p.33-42, 1999.

LIMA, M.R.F.; LUNA, J.S.; SANTOS, A.F.; ANDRADE, M.C.C.; SANT'ANA, A.E.G.; GENET, J.P.; MARQUEZ, B.; NEUVILLE, C.; MOREAU, N. Anti-bacterial activity of some Brazilian medicinal plants. J. Ethnopharmacol., v.105, n.1-2, p.137-147, 2006.

LISTER, R.G. The use of a plus maze to measure anxiety in the mouse. Psychopharmacology, v.92, p.180-185, 1987.

MALONE, M. H. Pharmacological approaches to natural product, screening and evaluation. In: . New natural products and plant drugs with pharmacological, biological or therapeutical activity. Berlin: Verlag. 1977. p.24-53.

MATOS, L.G.; SANTOS, L. DA R.; FERREIRA, R.N.; PONTES, I.S.; PAULA, J.R.; COSTA, E.A. Antiinflammatory, anti-nociceptive and sedating effects of Lafoensia pacari (PACARI) aqueous extract. Pharm. Biol., v.46, n.5, p.341-346, 2008.

MENEZES, V.M., ATALLAH, A.N., LAPA, A.J., CATAPANI, W.R. Assessing the Therapeutic Use of Lafoensia pacari St. Hil. Extract (Mangava-Brava) in the Eradication of Helicobacter pylori: Double-Blind Randomized Clinical Trial. Helicobacter., v.11, n.3, p.188-195, 2006. 
MÜLLER, V.; CHÁVEZ, J.H.; REGINATTO, F.H.; ZUCOLOTTO, S.M.; NIERO, R.; NAVARRO, D.; YUNES, R.A.; SCHENKEL, E.P.; BARARDI, C.R.; ZANETTI, C.R.; SIMÕES, C.M. Evaluation of antiviral activity of South American plant extracts against herpes simplex virus type 1 and rabies virus. Phytother. Res., v.21, n.10, p.970-974, 2007.

MUNDO, S.R.; DUARTE, M.R. Morfoanatomia Foliar e Caulinar de Dedaleiro: Lafoensia pacari A. St.-Hil. (Lythraceae). Lat. Am. J. Pharm., v.26, n.4 p.522-529, 2007.

MURAKAMI, S., ISOBE, Y., HIGIMA, H., NAGAI, H., MURAMATU, M., OTOMO, S. Inhibition of gastric $\mathrm{H}^{+} \mathrm{K}^{+}$ ATPase and acid secretion by ellagic acid. Planta Med., v.57, p.305-308, 1991.

PELLOW, S.; CHOPIN, P.; FILE, S.; BRILEY, M. Validation of open-closed arm entries in an elevated plus-maze as a measure of anxiety in the rat. J. Neurosci. Methods, v.14, n.3, p.149-167, 1985.

POTT, A.; POTT, V. Plantas do Pantanal. Brasília: EMBRAPACPAP, 1994. p.187.

RATES, S.M.K., Plants as source of drugs. Toxicon, v.39, n.5, p.603-613, 2001.

RODGERS, R. J.; COLE, J. C. The elevated plus-maze: Pharmacology, methodology and ethology. In: COOPER, S. J.; HENDRIE, C. A. Ethology and Psychopharmacology, Chichester: Wiley, 1994. p. 9-44.

ROGERIO, A.P.; SÁ-NUNES, A.; ALBUQUERQUE, D.A.; ANIBAL, F.F.; MEDEIROS, A.I.; MACHADO, E.R.; SOUZA, A.O.; PRADO, J.C.JR; FACCIOLI, L.H., Lafoensia pacari extract inhibits IL-5 production in toxocariasis. Parasite Immunol., v.25, n. 7, p.393-400, 2003.

ROGERIO,A.P.; FONTANARI, C., MELO, M.C.; AMBROSIO, S.R.; DE SOUZA, G.E.; PEREIRA, P.S.; FRANÇA, S.C.; DA COSTA, F.B.; ALBUQUERQUE, D.A; FACCIOLI, L.H. Anti-inflammatory, analgesic and anti-oedematous effects of Lafoensia pacari extract and ellagic acid. J. Pharm. Pharmacol., v.58, n.9, p.1265-1273, 2006.

ROGERIO, A.P.; SÁ-NUNES, A.; ALBUQUERQUE, D.A.; SOARES, E.G.; FACCIOLI, L.H. Anti-inflammatory effects of Lafoensia pacari and ellagic acid in a murine model of asthma. Eur. J. Pharmacol., v.508, n.1-2, p.262-270, 2007.
SANTOS, L. W. Estudos ecológicos e agronômicos de Lafoensia pacari St. Hil. (LYTHRACEAE) na região de Barra do Garças - MT. Cuiabá, 2006. 61 p. [Dissertação de Mestrado. Faculdade de Agronomia e Medicina Veterinária. Universidade Federal do Mato Grosso].

SCHENKEL, E.P.; GOSMANN, G.; ATHAYDE, M. L. In: SIMÕES, C. M. O. Farmacognosia: da planta ao medicamento. Porto Alegre/Florianópolis: Editora da UFRGS/Editora da UFSC, 2004. p.711-740.

SIEGEL, P. S. A simple eletronic device for the measurement of gross bodily activity of small animals. J. Psychol., v.21, n.2, p.227-236, 1946.

SILVA, S.R. Plantas do Cerrado utilizadas pelas comunidades da região do Grande Sertão Veredas. Brasília: FUNATURA, 1998. 109 p.

SOLON, S.; LOPES, L.; SOUSA JR, P.T.; SCHMEDAHIRSCHMANN, G. Free radical scavenging activity of Lafoensia pacari. J. Ethnopharmacol., v.72, n.1, p.173$178,2000$.

STEIN, D.J., SEEDAT, S. Unresolved questions about treatment-resistant anxiety disorders. CNS Spectr., v.9, n. 10, p.715, 2004

TONELLO, V. M. Estrutura de populações de Lafoensia pacari St. Hil. e dados etnobotânicos e fenológicos em Nossa Senhora do Livramento-MT. Cuiabá, 1997. 94 p. [Dissertação de Mestrado em Ecologia e Conservação da Biodiversidade. Instituto de Biociências. Universidade Federal de Mato Grosso].

VASCONCELOS, S.M.; MACEDO, D.S; MELO, C.T.; MONTEIRO, A.P.; RODRIGUES, A.C.; SILVEIRA, E.R.; CUNHA, G.M.; SOUZA,F.C.; VIANA, G.S. Central activity of hydroalcoholic extracts from Erythrina velutina and Erythrina mulungu in mice. J. Pharm. Pharmacol., v.56, n.3, p.389-393, 2004.

VIEIRA, R.F.; MARTINS, M.V.M. Recursos Genéticos de plantas medicinais do cerrado: uma compilação de dados. Rev. Bras. Pl. Med., v.3, n.1, p.13-36, 2000.

Received for publication on $02^{\text {nd }}$ October 2008 Accepted for publication on $01^{\text {st }}$ April 2010 